\title{
交流プラズマトーチにおける電極損耗に与える アーク電流および電極形状の影響
}

\author{
正員 岩 由 幹 正 (電力中央研究所) \\ 正員 渋 谷 正 豊 (電力中央研究所)
}

\author{
Effects of Arc Current and Electrode Size on Electrode Erosion in AC Plasma Torches \\ Mikimasa Iwata, Member, Masatoyo Shibuya, Member \\ (Central Research Institute of Electric Power Industry)
}

\begin{abstract}
Heavy erosion of the electrode is a problem in using AC plasma torches. In a series of our studies, the effects of electrode stem size (diameter and length) and tip shape on the electrode erosion were clarified at a low current of $200 \mathrm{~A}$. In this paper, on the basis of the $200 \mathrm{~A}$-data, in order to reduce the electrode erosion with the current increased, the effects of current and electrode size on electrode erosion were clarified experimentally and analytically at $100-550 \mathrm{~A}$. The electrode used was of solid type and the material was tungsten containing $2 \mathrm{wt} \%$ of lanthanum oxide. The plasma gas was argon. Main results are as follows.

(1) As the current increased, the electrode erosion increased linearly. In case of thin electrode $(8 \mathrm{~mm} \phi)$, at $450-$ $550 \mathrm{~A}$, the electrode tip was molten partially and the electrode erosion increased rapidly over $5 \mathrm{mg} / \mathrm{h}$. However, in case of thick electrode $(13 \mathrm{~mm} \phi)$, the electrode erosion did not increase rapidly.

(2) The temperature distribution along the electrode axis was calculated. As a result, a good correlation was obtained between the calculated temperature of electrode tip and the measured electrode erosion. As the tip temperature decreased to $3,000 \mathrm{~K}$ (c.f. tungsten melting point: $3,660 \mathrm{~K}$ ), the electrode erosion decreased below . $5 \mathrm{mg} / \mathrm{h}$ of the linearly increasing range.
\end{abstract}

キーワード : 交流プラズマトーチ, タングステン電極損耗, アーク電流, 電極先端温度

\section{1.まえがき}

アークプラズマ（以下，プラズマと略記）は，温度やエ ネルギ一密度が高く制御性に優れているなどの特長を持 ち合わせている。このため，金属の溶解や精練，製鉄など の金属産業分野, 燈暂物や有害物質の処理などの環境保全 分野における電気の有效利用技術として利用されている (1)(2)。ブラズマは，その供給電源の違いから直流プラズマ と交流プラズマとに分けられる。現在は，ブラズマトーチ (以下,ト一チと略記) 内の電極の損耗性やプラズマの安 定性の観点から，主に直流ブラズマが利用されている。一 方，交流プラズマには，複数のトーチ間に簡易にプラズマ を形成できるという特長があるため，導電性を持たない物 質でも加熱でき，また炉底電極も不要となり運転の簡易化 が期待できる。このような特長に着目して，最近，金属鋳 造ブロセス中のタンディッシュにおける溶鋼加熱(3)や烧 却フライアッシュ廃棄物の処理(4)などに利用されている。
しかし,プラズマ発生部分関連の課題として, 直流トーチ に比べてトーチ内の電極が損耗しやすいこと,電流零点で ブラズマが不安定になりやすいことなどが挙げられ(5)こ れらを解決することが望まれている。

これまで, 直流トーチの電極の損耗については, 材料学 的な検討など広く行なわれてきた(6)(7)が，交流卜一チの電 極損耗についてはそれほど検討されていない。筆者らは交 流トーチの電極の損耗について，小電流 $200 \mathrm{~A}$ における基 礎検討を電極形状の視点から行なった(8)。本論文では，前 報で得られた知見に基づいて，主にアーク電流が電極損耗 に与える影響に関して実験的および解析的検討を行ない， 低損耗化対策を明らかにする。

\section{2. 実験方法}

実験回路を図 1 に示す。トーチ電極先端部と対向電極上 端部に銅細線を張り，そこに電流を流して溶断・発弧させ， 
100 550A (実効値) の移行形の交流ブラズマを大気中で 発生させ, 1〜3 時間連続で安定に点弧させた。この際， プラズマガスはアルゴンとした。実験前後のトーチ電極重 量の隇少分を損耗量とした。また，ト一千電極の冷却水入 ロと出口に測温抵抗体（Pt100，JIS）を装着して，その 両箇所の水の温度差を温度差変換器（精度 : $\pm 0.06^{\circ} \mathrm{C}$ ) を 用いて測定した。その盜度差と冷却水流量とから，冾却水 が高温のトーチ電極から奪う熱量（抜熱量; 今回の実験条 件における精度は土 $38 \mathrm{~W}$ ）を算出した。なお，ト一チの外 面を通して熱が出入りしないようにト一千全体を断熱材 で覆った。

主な実験条件を表 1 に示す。一つの実験条件につき 2 〜4回ずつ実験を行なった。アーク電流およびトーチ電極 の電極形状 (主に電極径) をバラメータとした。また，前 報(8)で得られた知見に基ついて，電極先端を平坦にして電 極先端面積を大きくすることにより先端部分の熱抵抗を 小さくした。なお，トーチの電極材料は酸化ランタン入り タングステンを用いた。

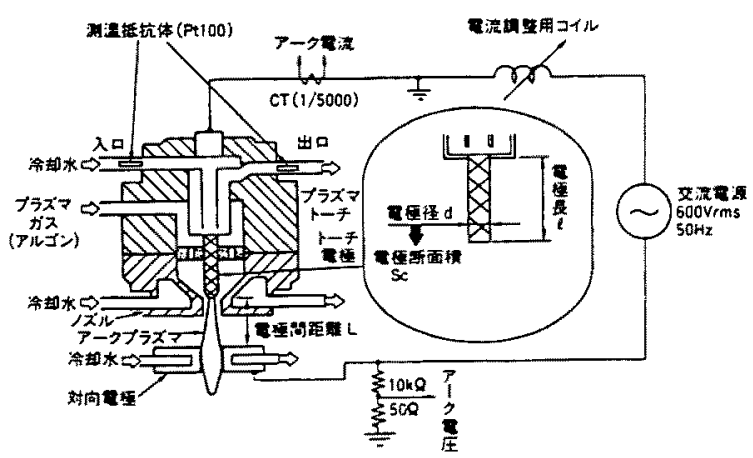

図 1 実験回路

Fig.1. Experimental circuit and vertical-section diagram of a plasma torch in test.

表 1 主な実験条件

Table 1. Experimental conditions.

\begin{tabular}{|c|c|c|}
\hline $15 \bar{x}-9$ & \multicolumn{2}{|c|}{ 敖定条件 } \\
\hline アーク形湓 & 傮行形 & \\
\hline アーク梳 & 交流 $100 \sim 5050 A_{\mathrm{mm}}$ & \\
\hline 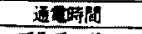 & $1 \sim 3$ 時陷 & \\
\hline ブラスマカス & 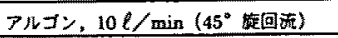 & \\
\hline 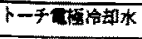 & $9 \ell / \min , 5^{\circ} \mathrm{C}($ (e) & \\
\hline 交法视 & $600 \mathrm{~V}_{\text {rmas. }}, 50 \mathrm{~Hz}$ & \\
\hline F一千西栖 & 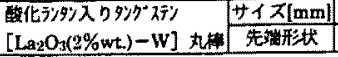 & $\begin{array}{l}\phi 8 \times 12, \phi 10 \times 12, \phi 13 \times 11 \\
\text { 平些拢 }\end{array}$ \\
\hline $1 \pi \mu$ & 製で孔梶 $10 \mathrm{~mm} \phi$ & \\
\hline 村间骨顺 & 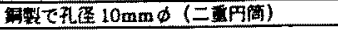 & \\
\hline 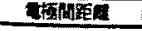 & $L=30 \mathrm{~mm}$ & \\
\hline
\end{tabular}

\section{3. 実験結果}

<3.1>冷却水によるトーチ電極からの抜熱量図 2 に,アーク電流および電極形状をパラメータとした場合の， 冷却水によるトーチ電極からの抜熱量を示す。いずれの電 極形状の場合も,アーク電流の增加とともに抜熱量は増加 した。また，電極径が大きい方が抜熱量は大きいことが分

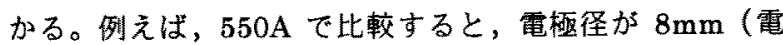
極断面積: $50 \mathrm{~mm}^{2}$ ) の場合，拔熱量は $1,400 \mathrm{~W}$ 程度であ るが, $13 \mathrm{~mm}$ (電極断面筫 : $133 \mathrm{~mm}^{2}$ ) の場合, 抜熱量は $1,800 \mathrm{~W}$ 程度と前者に比べ約 3 割大きい。なお,これらの デー夕は第 4 章の考察で利用する。

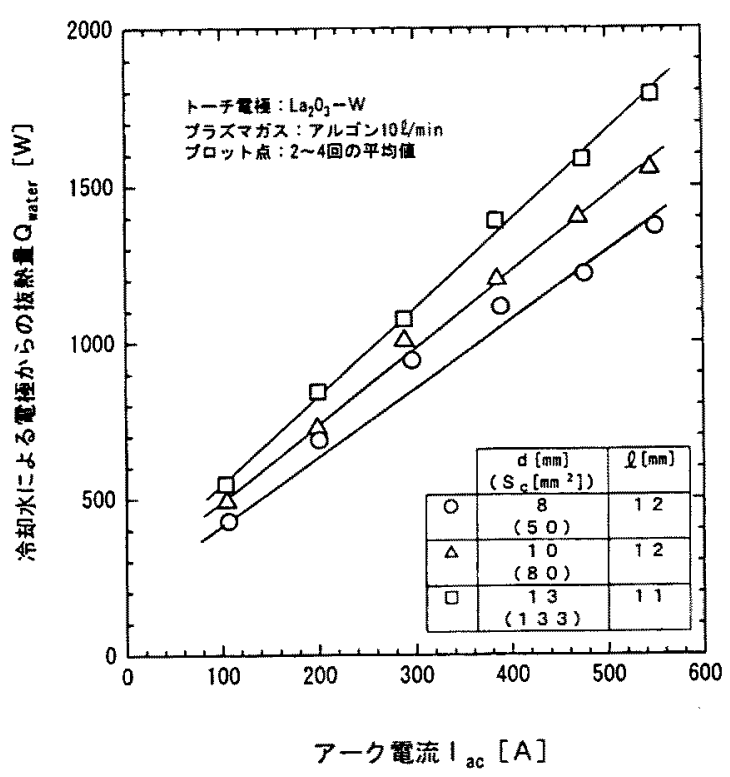

図 2 泠却水による抜熱量のアーク電流依存性

Fig.2. Dependence of electrode coolant loss on arc current.

<3.2>トーチ電極の損耗量図 3 に,アーク電流およ び電極形状をパラメータとした場合のトーチ電極の損耗 量を示す。いすれれ電極形状の場合も，アーク電流の增加 とともに損耗量は增加した。このような損耗量の增加は, 電極表面の溶融・蒸発現象がアーク電流の增大によって活 発化するためと考えられる。また，電極径が $8 \mathrm{~mm} や 10 \mathrm{~mm}$ の場合は 450〜 550A で損耗量は急增したが，電極径が $13 \mathrm{~mm}$ の場合は $550 \mathrm{~A}$ でも損耗量の急增は見られなかっ た。このような，ある電流值以上での損耗量の急增現象は， 前述の溶蛬・蒸発現象がより一層顕著になるためと考えら れる。実システムを考虑すると，損耗量が急増しない範囲 を把握する必要があると思われる。そこで, 次節以降, 今 回の実験条件において損耗量が急增しない筙囲について 検討を進めることにする。具体的には，図 3 から $5 \mathrm{mg} / \mathrm{h}$ 以下では急增していないと見なし，主にその範囲の条件に ついての検討を行なう。 


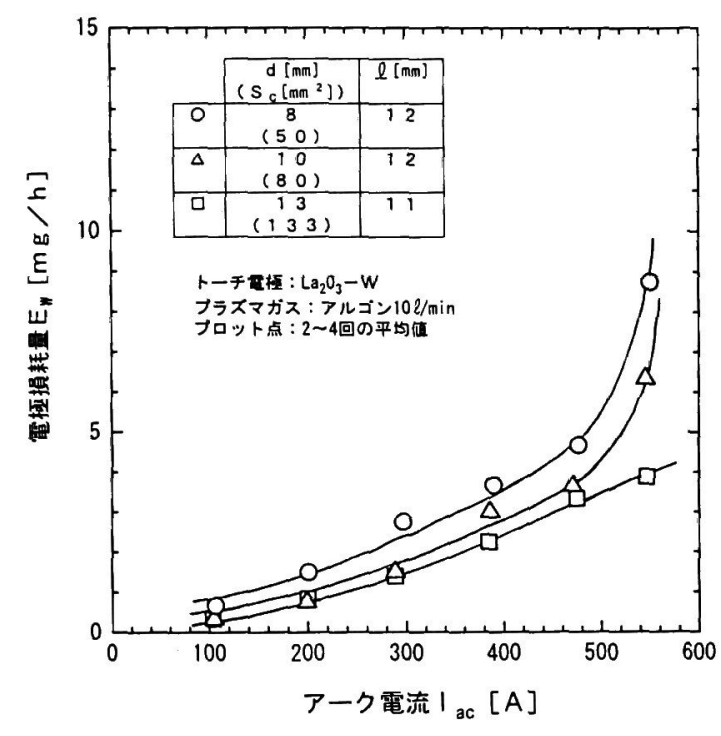

図 3 電極損耗量のアーク電流依存性

Fig.3. Dependence of electrode erosion weight on arc current.

$<3.3>$ 実験後の電極先端部分の状況観察図 4 に, ア 一ク電流 550A で $1 \mathrm{~h}$ 通電後の電極先端部分の状況の一例 を示す。図(a)は電極径が $13 \mathrm{~mm}$ の場合で損耗量が $4 \mathrm{mg} / \mathrm{h}$ のケースである。この場合，電極先端は溶融がほとんど認 められず, 電極先端部分の平均的な温度が融点より低いと 推測される。一方，図(b)は電極径が $8 \mathrm{~mm}$ の場合で損耗量 が $9 \mathrm{mg} / \mathrm{h}$ のケースである。この場合，電極先端は部分的 な溶融が認められ, 電極先端部分の平均的な温度は融点に 達していると推測される。以上のことから，電極損耗量の 急増現象は電極先端温度と相関関係があると考えられる。

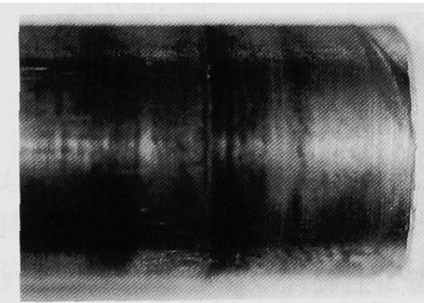

(a) 損耗量が少ない場合 $\left[E_{w}=4 \mathrm{mg} / \mathrm{h}, \quad d=13 \mathrm{~mm} \phi, \ell=11 \mathrm{~mm}\right]$

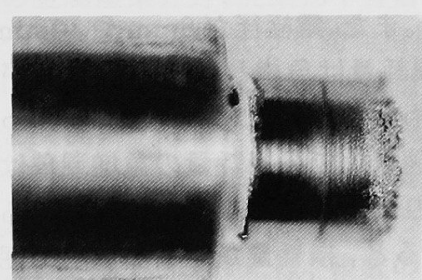

(b) 損耗量が多い場合

$\left[E_{w}=9 \mathrm{mg} / \mathrm{h}, d=8 \mathrm{~mm} \phi, \ell=12 \mathrm{~mm}\right]$

図 4 実験後のト一千電極先端部分の状況

(交流 550Arms，1 h, $\mathrm{La}_{2} \mathrm{O}_{3}-\mathrm{W}$ )

Fig.4. Photographs of electrodes after experiment.

\section{4. 電極損耗量と電極先端温度の相関関係に関す る考察}

本章では,トーチ電極の損耗に影響を及ぼす因子の一つ と考えられる電極の先端温度に着目し, その先端温度と損 耗量との間の関係を検討した。まず,トーチ電極における 入・出熱量の試算を行ない, 次に, この結果を用いて電極 軸方向の温度分布を計算し, 電極先端の温度を算出した。 <4.1>トーチ電極における入・出熱量の試算阮 電極において出入りする代表的な熱量 ${ }^{(8)}$ を今回の実験条 件の場合について試算を行なった。代表的な諸熱量は以下 の通りである。

[I]電極に入ってくる熱量 $Q_{\text {in }}$ (入熱量)

(1)電極降下電圧に起因する入熱量 $Q_{d r o p}$

(2)プラズマからの放射光による入熱量 $Q_{r a d A}$

(3)電極内部でのジュール発熱量 $Q_{R I}{ }^{2}$

[II]電極の極性が「正」のときに電極に入ってきて，「負」の ときに出ていく熱量

(4)電子が出入りする際に発生する熱量 $Q_{\text {ele }}$

[III]電極加出ていく熱量 $Q_{o u t}$ (出熱量, 抜熱量)

(5)冷却水による抜熱量 $Q_{\text {water }}$

(6)ガスによる抜熱量 $\boldsymbol{Q}_{\text {gas }}$

(7)高温の電極先端面から周囲空間への幅射伝熱量 $Q_{r a d E}$

(8)電極先端の一部が溶融する際に使われる熱量 $Q_{m e l t}$

(9)電極先端の一部が蒸発する際に使われる熱量 $Q_{\text {vapor }}$ これら諸熱量の試算方法は前報(8)と同様であるが,ここで も簡単に述べる。 $Q_{r a d A}$ は，アーク電圧から電極降下電圧 (今回の条件では約 $15 \mathrm{~V}^{(9)(10)}$ ) を差し引いた電圧にアー ク電流を乗じたアークコラムパワーの約 3 割(11)が電極先 端に入射するとして求めた。 $Q_{R I}{ }^{2}$ は, 電極の電気抵抗の 温度依存性(12)を考慮したものと電流の 2 乗との積として 求めた。 $Q_{g a s}$ は, 熱伝達係数を $100 \mathrm{~W} /\left(\mathrm{K} \cdot \mathrm{mm}^{2}\right)^{(13)}$, 熱 伝達面を電極側面, 電極と電極周辺との温度差を $1,000 \mathrm{~K}$ として求めた。ここで, 後述する解析方法で求めた電極の 平均温度は $1,000 \sim 1,500 \mathrm{~K}$ であり,これと周辺温度 $(300 \mathrm{~K}$ と仮定) との差を約 $1,000 \mathrm{~K}$ と見積もった。 $Q_{\mathrm{radE}}$ は，シ ュテファン・ボルッマンの放射法則の式により求めた。夕 ングステン電極の放射率を $0.35^{(14)}$, 電極先端温度を $3,000 \mathrm{~K}$, 熱放散面積を電極先端面積として求めた。ここ で, 後述する解析方法で求めた電極先端温度は $3,000 \mathrm{~K}$ 前 後であり，この温度を用いた。 $Q_{\text {melt }}$ および $Q_{\text {vapor }}$ は，今 回の実験結果 (損耗量) から試算すると, それぞれ数 $\mathrm{mW}$ および数十 $\mathrm{mW} て ゙ あ っ た 。 Q_{\text {ele }}$ は, 交流電流を対象とし ているので 0 とした。また， $Q_{d r o p}$ (1) 以外の熱量（2 〜9) の試算を行なったうえで， $Q_{i n}=Q_{\text {out }}$ と仮定して $Q_{d r o p}$ を求めた。なお, 上記の試算熱量の中には電極温度 をもとにして求めているものがあるが, 後述する電極温度 の解析方法における電極通過熱量は実測值の $Q_{\text {water }}$ が大 部分を占めているために, 試算熱量の誤差による電極温度 
への影響はほとんどないと考えられる。

試算熱量の代表的な例として電極径が $13 \mathrm{~mm}$ の場合の 結果を図 5 に示す。図(a)がト一千電極における入熱量 $Q_{i n}$ であり，図(b)がトーチ電極における出熱量 $Q_{o u t}$ である。 この図から次のことが分かる。

(1) アーク電流の增加とともに熱量 $Q_{\text {in }}\left(Q_{o u t}\right)$ も增加する。 (2) 全入熱量 $Q_{i n}$ のうち $Q_{d r o p}$ が大部分 (7〜8 割) を占め ている。

（3）アーク電流が增加すると，主に $Q_{d r o p}$ が增加するため に $Q_{\text {in }}$ が増加する。

(4) 全拔熱量 $Q_{\text {out }}$ のうち $Q_{\text {water }}$ (実測值) が大部分（8 〜9割)を占めている。

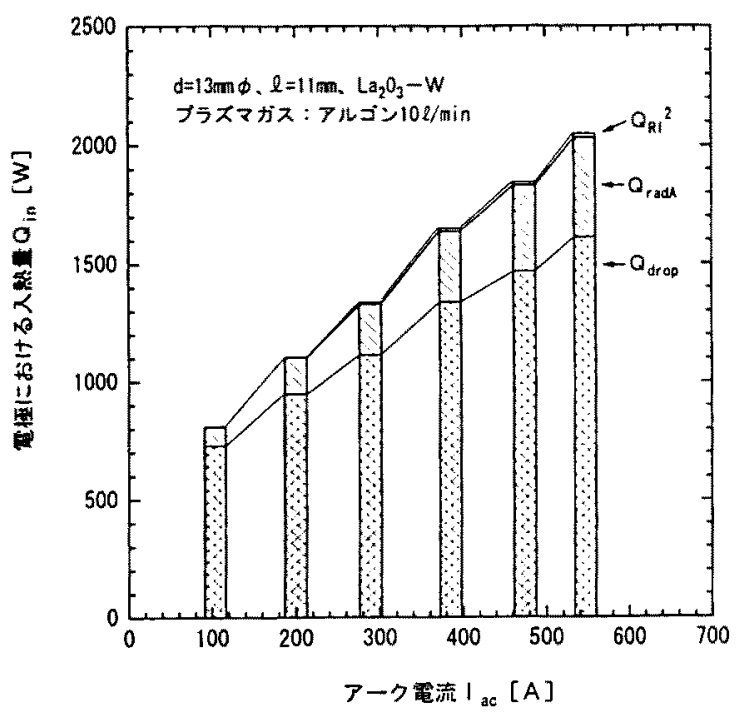

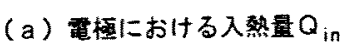

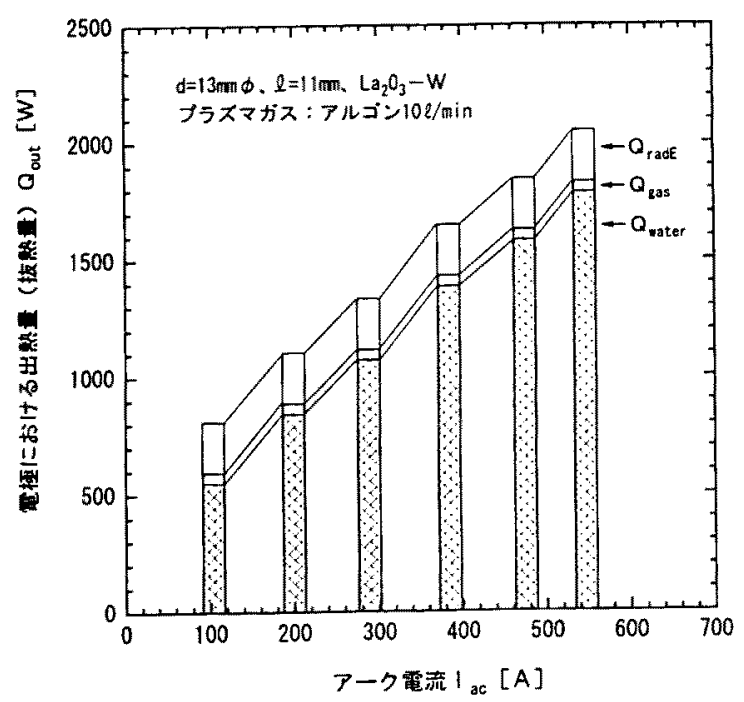

(b) 電極における出熱量 $Q_{\text {out }}$

図 5 トーチ電極における入・出熱量のアーク電流 依存性 $(\mathrm{d}=13 \mathrm{~mm} \phi, \ell=11 \mathrm{~mm})$

Fig.5. Dependence of heat balance in the electrode on arc current.
なお,これらのことに関しては他の電極径の場合も同様の 傾向を示した。

\section{$<4.2>$ 電極先端温度の計算}

（1）計算手法 前節の結果老用いて，図6に示すよう な方法で前報(8)とほぼ同様に分割メッシュ数 $n$ と矿と し電極内部の軸方向の一次元定常熱伝道の解析を行ない, 電極先端の温度を算出した。なお，熱量 $Q_{g a s}$ は電極側面 から徐々に分割メッシュことに周囲ガスに复われていく と考えられるが，今回は，最も泠却水側の分割メッシュ(図 中の 1-2 間) で $Q_{g a s}$ 全量が奪われるとし，その他の分割 メッシュでは電極内部を通過する熱量 $Q$ を一定值 $\left(Q_{i n}-\right.$ $\left.Q_{r a d E}\right)$ とした。これは, 電極のサイズや形状などの設計 を行う際には，<3.3>節で推定したことからも分かるよう に，電極先端温度を高く見積もった方が電極損耗量の低減 化という観点からは安全サイドと考えられるからである。 なお，最も電極先端側の分割メッシュ（図中のn-(n-1)間) で $Q_{g s s}$ 全量が复われるとして電極先端温度を算出したと ころ $100 \mathrm{~K}$ 程度の違いがあるものの大きな差異はないと 思われる。
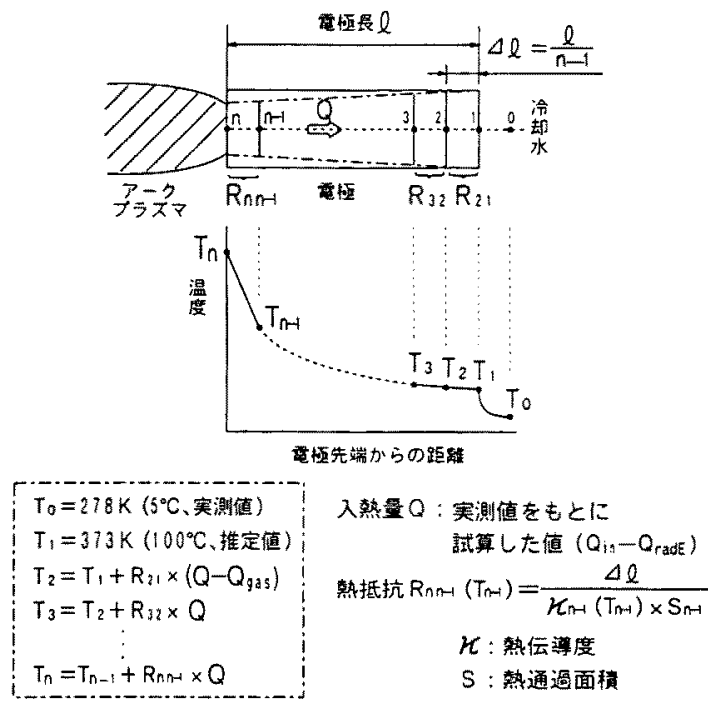

図 6 トーチ電極の温度分布計算手法

Fig.6. Calculation method of temperature distribution along electrode axis.

なお，前報と異なる点を以下に述べる。前報では，電極 径が細く，また，電極先端が円錐台状であったために，プ ラスママは電極先端全面に点弧していた。一方，今回は，図 $4(a)$ 実験後の電極先端状況（アーク痕跡）加ら分かる上 うに，電極径が太くて電極先端が平坦状であるため，プラ ズマは電極先端全面には点弧せずに一部分に点弧してい る。このため，熱通過部分が電極全体ではないと考え，図 6 に示すように電極先端のアーク痕跡から電極泠却水と 接しているところに向けて，電極先端からの距離の 2 次関 数として熱通過面積が增加していくと仮定して解析䘮行 
なった。なお，今回の条件でのアーク痕跡面積は，いずれ の電極形状の場合もアーク電流の增加とともにほぼ比例 して增加しており，その比例係数は $0.09 \mathrm{~mm}^{2} / \mathrm{A}$ であっ た。このような電極上のアーク痕跡に関しては大電流領域 (4,000 9,000A) でも調べられており(5), アーク電流が 増加してもその比例係数はほぼー定で $0.08 \sim 0.1 \mathrm{~mm}^{2} / \mathrm{A}$ であり，今回の結果とほぼ一致していることが分かる。

(2)計算結果および検討 アーク電流および電極形状 が異なる場合に電極先端温度 $T_{t}$ を算出したものを図 7 に 示す。この図から次のことが分かる。

(i) いずれの電極形状の場合も,アーク電流の增加ととも に電極先端温度は上昇する。

(ii) 電極径が小さいほど電極先端温度が高くなり, 電極径 が $8 \mathrm{~mm}$ で電流が $550 \mathrm{~A}$ の場合には融点近くまで上昇 している。この結果は, 3.3 節で電極先端部分の状沉 から推測したこととほぼ合致している。

なお，電極径が $13 \mathrm{~mm}$ の場合, 電流が $550 \mathrm{~A}$ の場合でも 電極先端温度は $2,600 \mathrm{~K}$ 程度と算出されている。この温度 は，電極が電子放出する温度領域の下限値付近であり，実 際の温度よりも若干低く算出されていると思われる。これ については次のように考えている。電極径が太い場合は電 極先端面積も大きく，先端面でアークスポットが動き回る 範囲が広がる。このため,アーク痕跡を入熱面積とみなし た今回，実際の入熱面積よりも大きく見積もり，電極先端 温度を低く算出したと考えられる。入熱面積の正確な同定 は今後の課題と考えている。

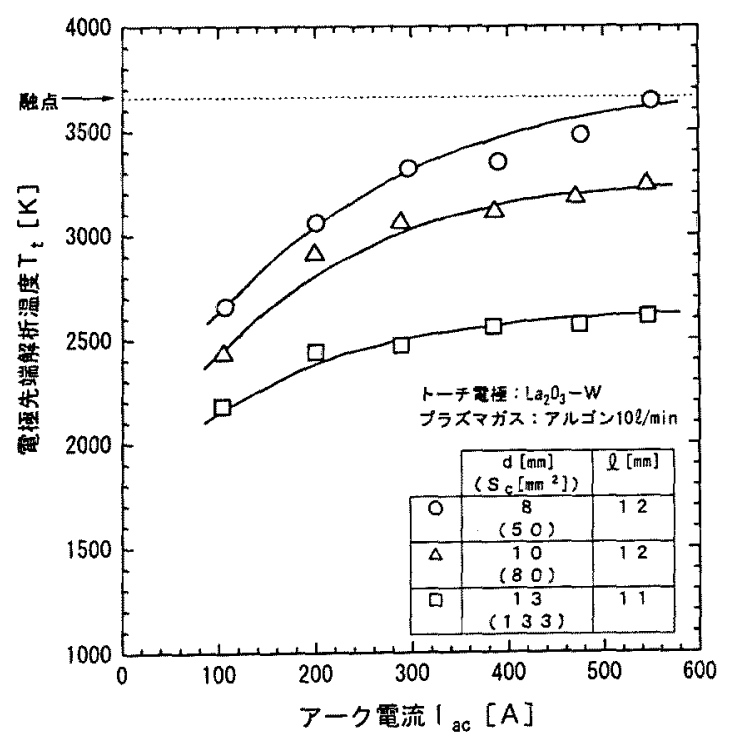

図 7 電極先端温度のアーク電流依存性

Fig.7. Dependence of calculated temperature of electrode tip on arc current.

$<4.3>$ 電極先端解析温度と電極損耗量 前節で求め た電極先端解析温度と電極損耗量 (実測檤)との関係を図
8 に印で示す。なお, 前報(8)のデータも同図にマ印で併 せて示す。この図から, 電極先端温度が低いほど損耗量が 低く抑えられていることが分かり，簡易な計算手法で解析 した電極先端温度を用いても概略の傾向を把握できた。ま た，前述したように損耗量の急增しない範囲を $5 \mathrm{mg} / \mathrm{h}$ 以 下と仅定すれば，その範囲に抑えるためには電極先端解析 温度を $3,000 \mathrm{~K}$ 程度以下（融点: $3,660 \mathrm{~K}$ ）に低減すればよ いことが分かる。

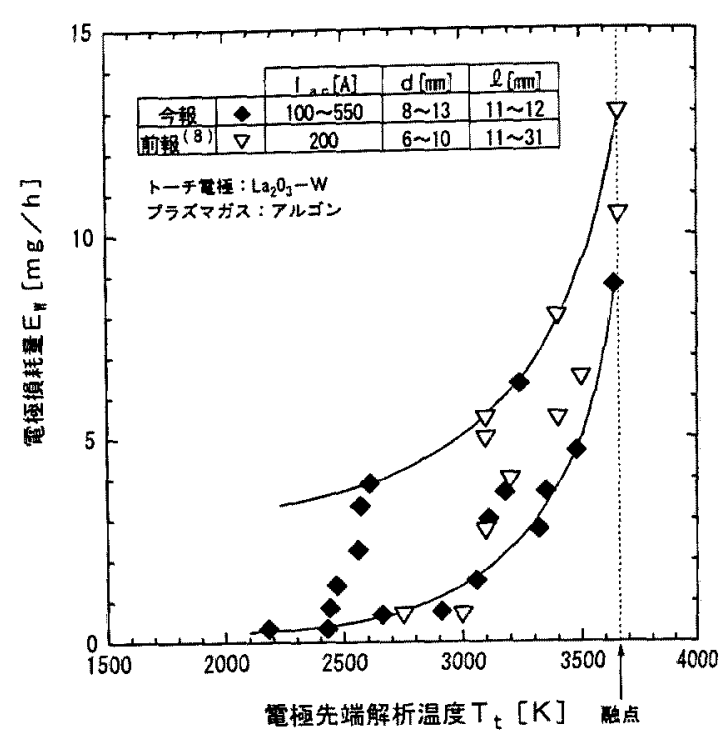

图 8 電極損耗量の電極先端温度依存性

Fig.8. Relation between measured electrode erosion weight and calculated temperature of the electrode tip.

\section{5.まとめ}

主にアーク電流が交流ト一チの電極損耗に与える影響 について実験的および解析的検討を行なった。まず，実験 用のブラズマトーチを用いて移行形の交流ブラズマを 1 〜3 時間連続で安定に点弧させ,ア一ク電流が 100 550A の場合の電極損耗実験を行なった。次に，今回の実験結果 などを基にして，電極における入・出熱量の試算，電極軸 方向の温度分布計算を行ない電極の先端温度を算出し,そ の温度と電極損耗量 (実測值) との関係を明らかにした。 その結果,電流を増加させたとき損耗量が急增しない範囲 (5mg/h 以下) にするには電極先端の温度を $3,000 \mathrm{~K}$ 程度 以下（融点: $3,660 \mathrm{~K}$ ) に低減することが必要であること を明らかにした。

最後に，本研究を行なうにあたり，当研究所今城尚久 電力部長を始めとする電力部の各位, 特に, アークプラズ マ研究関係各位には終始, 御指導ならびに御助言を睗った。 ここに，銘記し深く感謝いたします。

(平成 9 年 1 月 23 日受付) (平成 9 年 5 月 15 日再受付) 
文献

(1) 稲葉・渋谷:「プラズマトーチの適用例と今後の展望」, 電学誌, 107, 1019 (昭 62-10)

（2）鬼頭・横水：「最近のアーク物理と大電流遮断・アー ク応用技術」, 電学論 $B, 113,845$ (平 5.8)

（3）藤本・斎藤・清水・清川・入谷・西：「タンディッシ 工内溶鋼加熱用交流プラズマトーチの電力特性と溶 鋼加熱特性」鉄と鋼, 77, No.10, 1649 (1991)

(4) M.J.Copsey : "Commercial Applications of Plasma Technology in Western Europe", 2nd Int. Plasma Symposium Conf.(1992-3)

(5) H.J.Bebber : "AC TORCHES", 1st Int. Plasma Symposium Conf.(1990-3)

(6) M.Ushio, A.A.Sadek, K.Tanaka, G.Adachi \& F.Matsuda : "Effect of Grain Morphology on Consumption of GTA Electrode", JWRI, Trans., 20, No.2 (1991)

（7）田中・牛尾：「大容量プラズマトーチ用タングステン 陰極材料の開発」, 電気学会開閉保護研資, SP.96-17 (平 8-6)

(8) 岩田・安井・渋谷：「交流プラズマトーチにおける電 極の損耗現象に与える電極形状の影響」, 電学論 $\mathrm{A}$, 114,628 (平 6-9)

(9) 電気学会編 : 改定新版 放電ハンドブック，154,才 一兀社（昭 49）

(10)岩田・沵谷・稲葉：「プラスマトーチ用電極における 熱バランスーアーク電流および電極形状の影響一」, 平 5 電気学会全大論, No.123 (平 5)

(11) 二俣・横水・松村・鬼頭：「10kA 級アルゴンガス吹 付けアークにおける全放射パワー」, 平 5 電気学会全 大論, No.112 (平 5)

(12) タングステンモリブデンエ業会編 : タングステン・モ リブデン技術資料，10（昭 63）

(13) 甲藤：伝熱概論， 23 ，養賢堂 (平 2)

(14) 真鍋：Emmissivity，赤外線技術，9，68（昭 59）
岩田幹正 (正員) 1964 年 5 月 14 日生。1990年 3

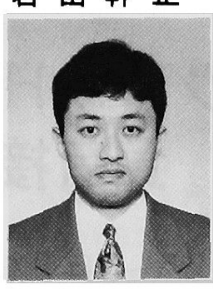
月名古屋大学大学院工学研究科博士課 程前期課程修了。同年 4 月（財）電力中 央研究所入所。現在, 横須賀研究所電力 部所属。主として,プラズマトーチにお ける電極・プラズマ現象に関する研究に 従事。

渋谷 正曾 （正員）1945 年 6 月 26 日生。1968 年 3

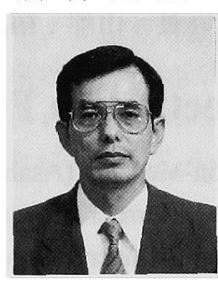
月関東学院大学工学部二部電気工学科 卒業。1964 年 4 月（財）超高圧電力研 究所入所, 1977 年 7 月（財）電力中央 研究所入所。現在, 横須賀研究所電力部 所属。主として, 電力機器における大電 流アーク現象, アークプラズマ応用技術 および有害物の無害化処理技術に関する研究に従事。 